\title{
PERSEPSI SERVANT LEADERSHIP PERGURUAN TINGGI DI KOTA PALU
}

\author{
Harnida W. Adda \\ Pricylia Chintya Dewi Buntuang \\ Jurusan Manajemen, Fakultas Ekonomi, Universitas Tadulako \\ email: harnidaadda@gmail.com; pricyliabuntuang@gmail.com
}

\begin{abstract}
Leadership gives its own color in organizational management. Leadership style that suits the character of the organization will contribute in the effectiveness of decision making and policy making. The college as Center of Excellent is required to be able for answer the challenges of environmental change with creating graduates who have qualities that match the demand of the labor market. Servant leadership leadership style is seen as one of the leadership styles that are able to fulfill that goal. Therefore, this study is intended to analyze the character servant leadership that is owned by the ranks of university leaders. This research was conducted by survey method to several public and private universities in Palu City to see the implications of leadership perception. The results of this study indicate that the leadership of several universities in Palu City has servant leadership character on various aspects such as trying to build relationships, maintaining group cohesiveness, and appreciating spiritual development, self-introspection, appreciating the development of professionalism, listening to others, individual persuasion, persuasive approach, striving for vision, prioritizing problem solving, believing in institutions to improve living standards, believing that members have intrinsic value, and generally being able to understand the needs of others, but in particular leaders have not fully understood the specific needs every member of the organization in the college he leads
\end{abstract}

Keywords: servant leadership, College.

\section{ABSTRAK}

Kepemimpinan memberikan warna tersendiri dalam manajemen organisasi. Gaya kepemimpinan yang sesuai dengan karakter organisasi akan memberi kontribusi dalam efektivitas pengambilan keputusan dan penetapan kebijakan. Perguruan tinggi sebagai The Center of Excellent dituntut untuk mampu menjawab tantangan perubahan lingkungan dengan menciptakan lulusan yang memiliki kualitas yang sesuai dengan permintaan pasar tenaga kerja. Gaya kepemimpinan servant leadership dipandang sebagai salah satu gaya kepemimpinan yang mampu memenuhi tujuan tersebut. Oleh karena itu, penelitian ini dimaksudkan untuk menganalisa karakter kepemimpinan servant leadership yang dimiliki oleh jajaran pimpinan perguruan tinggi. Penelitian ini dilakukan dengan metode survey ke beberapa perguruan tinggi negeri dan swasta yang ada di Kota Palu untuk melihat implikasi persepsi kepemimpinan. Hasil penelitian ini menunjukkan bahwa pimpinan beberapa perguruan tinggi di Kota Palu memiliki karakter kepemimpinan servant leadership pada berbagai aspek diantaranya berusaha membangaun jalinan silaturahmi, menjaga kekompakan kelompok, dan menghargai perkembangan spiritual, introspeksi diri, menghargai perkembangan profesionalisme, mendengarkan orang lain, berprasangka baik, menghargai perkembangan individu, melakukan pendekatan persuasif, berusaha mewujudkan visi, mengutamakan intuisi memecahkan masalah, percaya pada institusi untuk memperbaiki taraf hidup, percaya bahwa anggota memiliki nilai intrinsik, dan secara umum mampu memahami kebutuhan orang lain, namun secara khusus pemimpin belum sepenuhnya dapat memahami kebutuhan khusus setiap anggota organisasi di perguruan tinggi yang dipimpinnya.

Kata kunci: servant leadership, perguruan tinggi.

\section{PENDAHULUAN}

Pendidikan tinggi merupakan institusi yang bergerak dalam pengetahuan yang aktivitas intinya terkait dengan penciptaan dan diseminasi pengetahuan, serta pembelajaran. Institusi pendidikan tinggi saat ini menghadapi dunia yang lebih saling terkoneksi baik dalam pengetahuan, kreativitas, dan inovasi sebagai sesuatu elemen penting dalam perubahan masyarakat. Tekanan dunia global yang 
seperti ini, dicirikan pada dua hal percepatan dalam pertumbuhan masyarakat ilmu pengetahuan yang memiliki kecenderungan pada penguatan teknologi informasi dan komunikasi dan yang kedua adalah proses percepatan dan inovasi yang membawa pada ketidakpastian identitas, dunia kerja maupun karir. Berada pada situasi ini maka institusi pendidikan tinggi dihampir semua bagian dunia berusaha mencari berbagai cara dalam memelihara keberlanjutannya.

Pendidikan tinggi terutama universitas atau perguruan tinggi merupakan instrumen utama dalam masyarakat untuk secara terus menerus menciptakan pengetahuan. Manajemen pengetahuan pada perguruan tinggi yang mengelola personil, proses, dan teknologi akan sangat menentukan keberhasilannya dalam melayani masyarakat pengetahuan.

Perguruan tinggi negeri maupun swasta dalam hal ini menjadi sorotan utama dalam mencetak generasi-generasi yang siap dan mampu bersaing. Perguruan tinggi harus menyiapkan sumber daya manusia yang tangguh dan berkompeten agar tidak tergerus oleh situasi yang akan terus berubah. Persaingan yang begitu ketat, mengusahakan semua pihak untuk bisa bersaing dan tetap survive di lingkungan yang seperti ini. Representasi dari perguruan tinggi dalam menghadapi atau memanfaatkan kondisi seperti ini adalah cerminan perguruan tinggi tersebut dapat bersaing atau tidak.

Berkembangnya tuntutan kualitas dan juga dorongan teknologi dalam berbagai bidang, menjadikan perguruan tinggi harus terus menerus berkembang untuk dapat menghasilkan produkproduk akademik yang berguna bagi masyarakat. Dalam pengelolaan pendidikan tinggi, tuntutan perubahan tersebut dapat dilakukan secara efektif ketika kepemimpinan dan tatakelola dikembangkan dengan baik. Berbagai konflik internal dalam pengelolaan pendidikan pada umumnya terjadi karena kepemimpinan yang kurang baik.

Perguruan tinggi sebagai suatu organisasi memiliki karakteristik yang agak berbeda dengan organisasi lain. Struktur organisasi tradisional perguruan tinggi menunjukkan kekuasaan dan kewenangan berpusat pada departemen atau fakultas. Penelitian Baldridge tentang tata pamong perguruan tinggi menunjukkan bahwa hampir semua kekuasaan pembuatan keputusan terletak pada level departemen atau fakultas. Ciri lain yang menandai organisasi perguruan tinggi adalah praktik manajemen tidak terstruktur dan kontrol yang longgar, yang disebut oleh Cohen dan March (1974) sebagai anarki terorganisasi. Dengan karakteristik perguruan tinggi seperti itu, tentu saja dibutuhkan kepemimpinan yang berbeda dengan kepemimpinan pada organisasi lainnya (Handoyo, 2010).

Kepemimpinan yang dimaksud adalah kepemimpinan pelayan (servant leadership). Servant leadership pertama kali digagas oleh Robert K. Greenleaf pada tahun 1970 di sebuah esai berjudul The Servant as Leader. Greenleaf menyimpulkan bahwa pemimpin yang sukses harus menjadi pelayan. Ia percaya bahwa ini adalah sifat penting yang mengarah ke keberhasilan seorang pemimpin. Kualitas kepemimpinan sejati dikembangkan dari mereka memiliki keinginan yang mendalam untuk membantu orang lain. Greenleaf membahas perlunya pendekatan yang lebih baik untuk kepemimpinan, salah satunya melayani orang lain sebagai prioritas nomor satu. Kepemimpinan pelayan menekankan layanan peningkatan kepada orang lain, pendekatan holistik untuk pekerjaan, dan pembagian kekuasaan dalam pengambilan keputusan. Sejak itu, tulisan Greenleaf tentang kepemimpinan yang melayani telah mempengaruhi banyak penulis, pemikir, dan pemimpin (Goh \& Low, 2014).

Kepemimpinan pelayan melihat kepemimpinan dalam sudut pandang yang berbeda. Ini bukan tentang pengakuan, posisi, prestise atau status. Ini bukan tentang bagaimana mengontrol pengikut, namun kepemimpinan pelayan untuk membawa keluar potensi penuh dari para pengikut. Kepemimpinan yang memiliki jiwa pelayanan (servant leader) sebenarnya dapat dimulai dari dalam diri pribadi, hal ini karena kepemimpinan sejati dimulai dari dalam diri dan kemudian bergerak ke luar untuk melayani mereka yang dipimpinnya. Disinilah pentingnya karakter dan integritas seorang pemimpin untuk menjadi pemimpin sejati dan diterima oleh mereka yang dipimpinnya. Tujuan utama seorang pemimpin adalah melayani kepentingan mereka yang dipimpinnya. Orientasinya adalah bukan 
untuk kepentingan pribadi maupun golongannya tetapi justru kepentingan organisasi dan kepentingan mereka yang dipimpinnya.

Pemimpin yang melayani memiliki perhatian kepada mereka yang dipimpinnya. Perhatian itu mewujud dalam bentuk kepedulian akan kebutuhan, kepentingan, impian dan harapan dari mereka yang dipimpinnya. Pemimpin yang melayani merupakan pemimpin yang mau mendengar setiap kebutuhan, impian dan harapan dari mereka yang dipimpinnya, serta dapat mengendalikan kepentingan pribadinya di atas kepentingan organisasi atau mereka yang dipimpinnya. Mengendalikan kepentingan pribadi berarti dapat mengendalikan diri ketika tekanan maupun tantangan yang dihadapi menjadi begitu berat. Seorang pemimpin sejati selalu dalam keadaan tenang, penuh pengendalian diri dan tidak mudah emosi.

Sejak dikenalkan Robert Greenleaf, servant leadership menjadi subyek dalam teori organisasi dan menjadi pendekatan yang populer untuk berbagai organisasi termasuk institusi perguruan tinggi (Block, 1996; Greenleaf, 1977; Levering \& Moskowitz, 2000; Spears, 1995). Dalam pengelolaan pendidikan tinggi, tuntutan perubahan dapat dilakukan secara efektif ketika kepemimpinan dan tata kelola dikembangkan dengan baik. Berbagai konflik internal dalam pengelolaan pendidikan pada umumnya terjadi karena kepemimpinan yang kurang baik, untuk itu pemimpin di perguruan tinggi perlu memiliki gaya kepemimpinan pelayan (servant leadership). Hasil penelitian Handoyo (2010) menemukan bahwa servant leadership dapat menjadi alternatif kepemimpinan di pendidikan tinggi untuk melakukan perubahan organisasi dengan berhasil. Besarnya peranan pemimpin dalam perguruan tinggi juga dikemukakan oleh Bachtiar (2013) bahwa banyak faktor penentu daya saing perguruan tinggi, namun yang paling menentukan adalah kepemimpinan yang cakap dan bertanggung jawab, baik pada tingkat universitas maupun pada tingkat fakultas dan program studi. Untuk itu, pada penelitian ini fokus yang diambil adalah masalah persepsi servant leadership Perguruan Tinggi di Kota Palu.

\section{KAJIAN LITERATURE Servant Leadership}

Konsep kepemimpinan pelayan adalah mengubah pendekatan kepemimpinan secara evolusioner dan pribadi. Konsep ini bukanlah suatu perbaikan serba cepat atas persoalan-persoalan yang dihadapi pemimpin. Kepemimpinan pelayan menggunakan pendekatan mendasar dan bersifat jangka panjang, yang pada akhirnya akan memberikan perubahan secara menyeluruh pada kehidupan personal dan profesional pegawai.

Kepemimpinan pelayan adalah konsep kepemimpinan etis yang diperkenalkan oleh Greenleaf pada tahun 1970. Model kepemimpinan pelayan ini esensinya adalah melayani orang lain, yaitu pelayanan kepada karyawan, pelanggan, dan masyarakat, sebagai prioritas utama dan yang pertama. Lantu \& Rumahorbo (2007) mengatakan bahwa seorang pemimpin sejatinya adalah seorang pelayan. Liden et al. (2008) kepemimpinan pelayan menekankan integritas pribadi dan melayani orang lain, termasuk karyawan, pelanggan, dan masyarakat. McMinn dalam Stone et al. (2003) menyatakan bahwa pemimpin pelayan mengembangkan orang, membantu mereka untuk maju dan berkembang.

Irving dalam Oktavia dan Devie (2014) menyatakan bahwa servant leadership sebagai suatu proses dimana pemimpin dan para pengikutnya bekerja sama untuk mencapai visi organisasi. Selanjutnya Page dan Wong (2000) mendefinisikan servant leadership sebagai seorang pemimpin yang mau melayani orang lain dengan mengupayakan pembangunan dan kesejahteraan untuk memenuhi tujuan bersama.

Kepemimpinan pelayan adalah suatu model kepemimpinan yang memprioritaskan pelayanan kepada pihak lain, baik kepada karyawan (anggota) perusahaan, pelanggan, maupun kepada masyarakat sekitar. Praktik kepemimpinan pelayan ditandai dengan meningkatnya keinginan untuk melayani pihak lain dengan melakukan pendekatan secara menyeluruh pada pekerjaan, komunitas, 
serta proses pengambilan keputusan yang melibatkan semua pihak. Pemimpin pelayan mengenali kehormatan dan pentingnya nilai setiap individu karena mereka adalah ciptaan Tuhan yang mulia.

Prioritas utama dari kepemimpinan pelayan adalah pada bagaimana mengembangkan pihak lain (pengikut, komunitas internal, dan eksternal), bukan untuk mementingkan diri sendiri. Konsep kepemimpinan pelayan lebih menekankan pada pentingnya menghargai manusia sebagai makhluk ciptaan Tuhan, sehingga pemimpin menganggap bahwa pemberdayaan dan pengembangan pengikut adalah amanah yang harus dipenuhinya.

Selama ini para peneliti kepemimpinan yang melayani mengacu tulisan Greenleaf di atas jika ingin menjelaskan batasan dari kepemimpinan yang melayani. Spears (2010), salah satu pengikut Greenleaf telah merumuskan definisi tentang servant leadership sebagai "a new kind of leadership model...a model which puts serving others as the number one priority. Servant-leadership emphasizes increased service to others; a holistic approach to work; promotion a sense of community; and the sharing power in decision making”.

Spears kemudian menjabarkan satu persatu tentang apa itu "service to others, holistic approach to work, promoting a sense of community, dan sharing of power in decision making." Service to others, maksudnya pemimpin yang melayani itu dimulai ketika mengasumsikan posisinya sebagai pelayan dalam interaksinya dengan "pengikut". Kemudian, holistic approach to work, maksudnya pemimpin yang melayani itu berpegang pada prinsip, "Pekerjaan ada untuk orang, sama dengan orang hadir untuk pekerjaan". Promoting a sense of community, maksudnya kepemimpinan yang melayani mempertanyakan kemampuan institusi yang menyediakan pelayanan bagi masyarakat, karena hanya dengan memantapkan sense of community di kalangan pengikut maka sebuah organisasi dapat sukses sesuai dengan tujuannya. Sharing of power in decision making, maksudnya kepemimpinan yang efektif dilakukan melalui pengembangan kepemimpinan yang melayani pada orang lain. Melakukan pemberdayaan dan menyokong talenta pengikut. Intinya membagi kekuasaan kepada pengikut. Struktur organisasi dalam kepemimpinan yang melayani kadang-kadang dibuat seperti piramid terbalik, di mana karyawan, klien, dan stakeholder lainnya berada di atas, sementara pemimpinnya berada di bawah.

Kepemimpinan pelayan adalah sebuah konsep mengenai gaya/cara memimpin yang sangat baik/tepat untuk diterapkan dalam lingkungan pekerjaan. Timbulnya konsep ini disebabkan oleh terjadinya perubahan paradigma dalam konsep kepemimpinan. Dari paradigma lama yang memandang pekerja hanya sebagai salah satu faktor produksi saja, meriladi suatu paradigma baru yang menganggap pekerja sebagai suatu aset utama dalam suatu perusahan atau lembaga. Pekerja harus dipandang sebagai suatu pribadi yang utuh, yang memiliki perasaan, keinginan, kemmpuan, harga diri dan hak untuk mendapatkan kesejahteraan dan kebahagiaan hidup. Jadi seseorang yang ingin menjadi pemimpin pelayan haruslah mengubah paradigmanya terlebih dahulu.

\section{Karakteristik Servant Leadership}

Setelah Greenleaf mempopulerkan konsep tentang servant leadership, maka secara bertahap servant leadership mendapatkan popularitas dalam ranah ilmiah baik secara teoritis maupun secara empirik. Adapun perkembangan konstruk atau konsepsi servant leadership dibangun di atas konsepsi nilai-nilai dasar servant leader yang telah digagas oleh Greenleaf. Spears (1999); (2010) mengembangkan model servant leadership didasarkan pada 10 karakteristik yaitu listening, empathy, healing, awareness, persuasion, conceptualization, foresight, stewardship, commitment, and community building.

Farling et al. (1999) mengembangkan model servant leadership yang didasarkan pada 5 karakteristik yaitu vision, influence, credibility, trust, and service. Sementara Wong dan Page (2000) mengembangkan model servant leadership didasarkan pada 12 karakteristik servant leadership, kemudian Wong dan Page (2003) melakukan analisis faktor pada ukuran sampel yang cukup besar dan 
menghasilkan 8 faktor yaitu leading, servanthood, visioning, developing others, team-building, empowering others, shared decision making and integrity. Empat dari 12 faktor gagal muncul dan dihilangkan yang terdiri dari humility, caring for others, goal setting, and modeling.

Graham (2001) dalam Handoyo (2010) melihat servant leadership sebagai salah satu bentuk kepemimpinan karismatik yang paling besar dipengaruhi oleh moral, yang ditunjukkan oleh karakteristik terpentingnya berupa humility, relational power, autonomy, moral development of followers, dan emulation of leader's service orientation.

Russel \& Stone (2002) mengembangkan model servant leadership yang didasarkan pada 9 karakteristik yaitu vision, honesty, integrity, trust, service, modeling, pioneering, appreciation of others, empowerment. Patterson (2002) mengembangkan model servant leadership yang didasarkan pada 7 karakteristik yaitu agapao love, humility, altruism, vision, trust, empowerment, service. Barbuto dan Wheeler (2006) mengembangkan model servant leadership yang didasarkan pada 8 karakteristik yaitu altruistic calling, emotional healing, wisdom, persuasive mapping, organizational stewardship, humility, vision, dan service.

Sendjaya et al. (2008) mengembangkan model servant leadership yang didasarkan pada 7 karakteristik yaitu voluntary, subordination, authentic self, covenantal relationship, responsible morality, transcendental spirituality, transforming influence. Liden et al. (2008) mengembangkan model servant leadership yang didasarkan pada 9 karakteristik yaitu emotional healing, creating value for the community, conceptual skills, empowering, helping subordinates grow and succeed, putting subordinates first, behaving ethically, relationships and servanthood.

Penjelasan di atas menguraikan dimensi servant leadership yang dikembangkan para ahli. Untuk lebih jelasnya dapat dilihat dalam Tabel 1 .

Tabel 1 Dimensi Servant Leadership

\begin{tabular}{|c|l|ll|}
\hline No. & \multicolumn{1}{|c|}{ Dimensi Servant Leadership } & \multicolumn{1}{|c|}{ Sumber } \\
\hline 1. & $\begin{array}{l}\text { Listening, empathy, healing, awareness, persuasion, } \\
\text { conceptualization, foresight, stewardship, } \\
\text { commitment, and community building. }\end{array}$ & $\begin{array}{l}\text { Spears (1970) } \\
\text { (1999); (2010); Greenleaf }\end{array}$ \\
\hline 2. & Vision, influence, credibility, trust, and service. & Farling et al. (1999) \\
\hline 3. & $\begin{array}{l}\text { Leading, servanthood, visioning, developing others, } \\
\text { team-building, empowering others, shared decision } \\
\text { making and integrity. Humility, caring for others, } \\
\text { goal setting, and modeling. }\end{array}$ & Wong dan Page (2000); (2003) \\
\hline 4. & $\begin{array}{l}\text { Humility, relational power, autonomy, moral } \\
\text { development of followers, dan emulation of leader's } \\
\text { service orientation. }\end{array}$ & \begin{tabular}{l} 
Graham (2010) \\
\hline 5.
\end{tabular} $\begin{array}{l}\text { Vision, honesty, integrity, trust, service, modeling, } \\
\text { pioneering, appreciation of others, empowerment. }\end{array}$ & Russel \& Stone (2002) \\
\hline 6. & $\begin{array}{l}\text { Agapao love, humility, altruism, vision, trust, } \\
\text { empowerment, service. }\end{array}$ & Patterson (2002) \\
\hline 7. & $\begin{array}{l}\text { Altruistic calling, emotional healing, wisdom, } \\
\text { persuasive mapping, organizational stewardship, } \\
\text { humility, vision, dan service. }\end{array}$ & Barbuto dan Wheeler (2006) \\
\hline 8. & $\begin{array}{l}\text { Voluntary, subordination, authentic self, covenantal } \\
\text { relationship, responsible morality, transcendental } \\
\text { spirituality, transforming influence. }\end{array}$ & Sendjaya et al. (2008) \\
\hline 9. & $\begin{array}{l}\text { Emotional healing, creating value for the community, } \\
\text { conceptual skills, empowering, helping subordinates } \\
\text { grow and succeed, putting subordinates first, } \\
\text { behaving ethically, relationships and servanthood. }\end{array}$ & Liden et al. (2008) \\
\hline
\end{tabular}


Uraian beberapa dimensi yang dikemukakan oleh para ahli menunjukkan bahwa dimensi dari servant leadership sangat beragam dan memiliki karakteristik masing-masing. Oleh karena itu penelitian ini mencoba mengidentifikasi beberapa karakteristik dimensi servant leadership yang dianggap memiliki kesamaan dengan keadaan dan mampu menjawab permasalahan di lapangan. Hal tersebut menjadi dasar dalam melihat persepsi servant leadership perguruan tinggi itu sendiri dan peneliti tidak menentukan secara rinci dimensi yang digunakan, karena peneliti menggabungkan dari beberapa dimensi yang tertuang dalam kuesioner survey servant leadership.

\section{METODE PENELITIAN}

Penelitian ini menggunakan metode survey ke beberapa perguruan tinggi negeri dan swasta yang ada di Kota Palu selama kurang lebih 3 (tiga) bulan. Penelitian ini didesain secara kualitatif dengan pendekatan deskriptif. Bogdan dan Taylor dalam Basrowi dan Suwandi (2008:1) mengatakan bahwa penelitian kualitatif adalah salah satu prosedur penelitian yang menghasilkan data deskriptif berupa ucapan atau tulisan dan perilaku orang-orang yang diamati. Pendekatan kualitatif ini sangat sesuai untuk memahami dan menggambarkan fenomena sosial yang terjadi pada Perguruan Tinggi di Kota Palu. Dalam hal ini peneliti ingin memberikan gambaran secara mendalam tentang persepsi servant leadership Perguruan Tinggi di Kota Palu.

Populasi penelitian ini dosen Perguruan Tinggi di Kota Palu. Sampel penelitian ini sebanyak 30 orang yang ditentukan secara purposive atau secara sengaja dengan beberapa pertimbangan. Penentuan jumlah sampel tersebut didasarkan atas penarikan sampel pada beberapa Perguruan Tinggi di Kota Palu (Untad, Unismuh, STIE, IAIN, STIMIK, dan Unisa), masing-masing diwakili 5 orang sampel.

Pengumpulan data dalam penelitin ini dilakukan dengan observasi dan penyebaran kuesioner ke beberapa Perguruan Tinggi di Kota Palu.

Kuesioner dalam penelitian ini menggunakan skala Likert dengan kategori Hampir Selalu Terjadi (5); Sering Terjadi (4); Kadang-Kadang Terjadi (3); Jarang Terjadi (2); dan Tidak Pernah Terjadi (1). Data dalam penelitian ini dianalisis secara deskriptif yang bertujuan untuk mendeskripsikan atau menggambarkan data yang telah terkumpul sebagaimana adanya tanpa ada tujuan membuat kesimpulan untuk generalisasi. Beberapa hal yang dapat dilakukan dalam analisis deskriptif yaitu penyajian data melalui tabel distribusi frekuensi dengan persentase.

Tabel distribusi frekuensi untuk menentukan persentase tanggapan responden atas skor yang diperoleh dengan menggunakan rumus dari Sugiyono (2010:109) sebagai berikut:

Berdasarkan jumlah responden yang ditetapkan dalam penelitian ini sebanyak 30 orang responden, maka jumlah skor ideal (kriterium) untuk seluruh item $=5 \times 30=150$ dan yang terendah $=1 \times 30=30$.

\section{HASIL DAN PEMBAHASAN}

Kepemimpinan merupakan kemampuan seseorang mempengaruhi dan memotivasi orang lain untuk melakukan sesuatu sesuai tujuan bersama. Kepemimpinan meliputi proses mempengaruhi dalam menentukan tujuan organisasi, memotivasi perilaku pengikut untuk mencapai tujuan, mempengaruhi untuk memperbaiki kelompok dan budayanya. Kepemimpinan berbeda dengan kekuasaan. Kekuasaan merupakan kemampuan untuk mempengaruhi orang lain untuk mau melakukan apa yang diinginkan pihak lainnya, sedangkan kepemimpinan merupakan seni untuk mempengaruhi dan menggerakkan orang-orang sedemikian rupa untuk memperoleh kepatuhan, kepercayaan, respek, dan kerjasama secara loyal untuk menyelesaikan tugas.

Kepemimpinan menuntut suatu transformasi dari dalam hati dan perubahan karakter. Kepemimpinan sejati dimulai dari dalam dan kemudian bergerak ke luar untuk melayani orang-orang 
yang dipimpinnya. Karakter dan integritas seorang pemimpin sangat diutamakan untuk menjadi pemimpin sejati dan diterima oleh orang yang dipimpinnya. Seorang pemimpin boleh berprestasi tinggi untuk dirinya sendiri, tetapi itu tidak memadai apabila ia tidak berhasil menumbuhkan dan mengembangkan segala yang terbaik dalam diri para bawahannya. Pemimpin sebagai seorang yang mendapat amanah serta memiliki sifat, sikap, dan gaya yang baik untuk mengurus atau mengatur orang lain.

Pemimpin yang berhasil hendaknya memiliki beberapa kriteria yang tergantung pada sudut pandang atau pendekatan yang digunakan, apakah itu kepribadiannya, keterampilan, bakat, sifatsifatnya, atau kewenangannya yang dimiliki yang mana nantinya sangat berpengaruh terhadap gaya kepemimpinan yang akan diterapkan. Banyak konsep yang berkembang terkait dengan gaya kepemimpinan, tergantung di mana kepemimpinan tersebut diterapkan.

Kepemimpinan pada penelitian ini sedikit berbeda dengan kepemimpinan yang lainnya, karena kepemimpinan dalam penelitian ini menekankan pada karakter pelayan yang lebih dikenal dengan servant leadership (kepemimpinan pelayan). Kepemimpinan pelayan adalah suatu kepemimpinan yang berawal dari perasaan tulus yang timbul dari dalam hati yang berkehendak untuk melayani, yaitu untuk menjadi pihak pertama yang melayani. Pilihan yang berasal dari suatu hati itu kemudian menghadirkan hasrat untuk menjadi pemimpin. Pada intinya kepemimpinan pelayan adalah pendekatan jangka panjang yang memberikan perubahan kepada kehidupan dan kerja, pada pokoknya suatu cara memiliki keberadaan yang mempunyai peluang untuk menciptakan perubahan positif di seluruh kehidupan masyarakat.

Penelitian ini berusaha melihat persepsi servant leadership perguruan tinggi di Kota Palu. Penelitian ini dilakukan dibeberapa perguruan tinggi negeri dan swasta di Kota Palu dengan melakukan survei servant leadership yang bertujuan untuk mengetahui bagaimana penerapan servant leadership perguruan tinggi di Kota Palu. Servant leadership pada penelitian ini diliat dari beberapa dimensi yag dikemukakan oleh para ahli, di mana peneliti melakukan identifikasi beberapa dimensidimensi yang sesuai dan dapat diterapkan pada penelitian ini. Untuk mengetahui hal tersebut, maka dapat dilihat uraian secara deskriptif pada Tabel 2 berikut.

Tabel 2 Hasil Deskriptif Survey Servant Leadership

\begin{tabular}{|c|c|c|c|c|c|c|c|c|c|c|c|c|c|}
\hline \multirow{4}{*}{ No. } & \multirow{4}{*}{ Indikator } & \multicolumn{10}{|c|}{ Skor Tanggapan Responden } & \multirow{4}{*}{$\begin{array}{l}\text { Total } \\
\text { Skor }\end{array}$} & \multirow{4}{*}{$\%$} \\
\hline & & \multirow{2}{*}{\multicolumn{2}{|c|}{$\begin{array}{c}\text { HST } \\
5\end{array}$}} & \multirow{2}{*}{\multicolumn{2}{|c|}{\begin{tabular}{|r|} 
ST \\
4 \\
\end{tabular}}} & \multirow{2}{*}{\multicolumn{2}{|c|}{$\begin{array}{c}\text { KKT } \\
3 \\
\end{array}$}} & \multirow{2}{*}{\multicolumn{2}{|c|}{$\frac{\mathrm{JT}}{2}$}} & \multirow{2}{*}{\multicolumn{2}{|c|}{$\begin{array}{r}\text { TPT } \\
1\end{array}$}} & & \\
\hline & & & & & & & & & & & & & \\
\hline & & f & $\%$ & f & $\%$ & $\mathbf{f}$ & $\%$ & $\mathbf{f}$ & $\%$ & $\mathbf{f}$ & $\%$ & & \\
\hline 1 & $\begin{array}{l}\text { Mendengarkan orang } \\
\text { lain }\end{array}$ & 17 & 56,7 & 11 & 36,7 & 1 & 3,3 & 1 & 3,3 & 0 & 0,0 & 134 & 89,3 \\
\hline 2 & Berprasangka baik & 13 & 43,3 & 15 & 50,0 & 2 & 6,7 & 0 & 0,0 & 0 & 0,0 & 131 & 87,3 \\
\hline 3 & $\begin{array}{l}\text { Memahami kebutuhan } \\
\text { orang lain }\end{array}$ & 9 & 30,0 & 18 & 60,0 & 2 & 6,7 & 1 & 3,3 & 0 & 0,0 & 125 & 83,3 \\
\hline 4 & $\begin{array}{l}\text { Memahami kebutuhan } \\
\text { khusus setiap anggota }\end{array}$ & 3 & 10,0 & 16 & 53,3 & 10 & 33,3 & 1 & 3,3 & 0 & 0,0 & 111 & $\mathbf{7 4 , 0}$ \\
\hline 5 & $\begin{array}{l}\text { Menjaga kekompakan } \\
\text { kelompok }\end{array}$ & 20 & 66,7 & 9 & 30,0 & 1 & 3,3 & 0 & 0,0 & 0 & 0,0 & 139 & 92,7 \\
\hline 6 & Introspeksi diri & 17 & 56,7 & 12 & 40,0 & 1 & 3,3 & 0 & 0,0 & 0 & 0,0 & 136 & 90,7 \\
\hline 7 & $\begin{array}{l}\text { Melakukan pendekatan } \\
\text { persuasif }\end{array}$ & 13 & 43,3 & 13 & 43,3 & 4 & 13,3 & 0 & 0,0 & 0 & 0,0 & 129 & 86,0 \\
\hline 8 & $\begin{array}{l}\text { Berusaha mewujudkan } \\
\text { visi }\end{array}$ & 10 & 33,3 & 17 & 56,7 & 3 & 10,0 & 0 & 0,0 & 0 & 0,0 & 127 & 84,7 \\
\hline 9 & $\begin{array}{l}\text { Mengutamakan intuisi } \\
\text { memecahkan masalah }\end{array}$ & 9 & 30,0 & 17 & 56,7 & 4 & 13,3 & 0 & 0,0 & 0 & 0,0 & 125 & 83,3 \\
\hline
\end{tabular}




\begin{tabular}{|c|c|c|c|c|c|c|c|c|c|c|c|c|c|}
\hline 10 & Percaya pada institusi & 10 & 33,3 & 14 & 46,7 & 6 & 20,0 & 0 & 0,0 & 0 & 0,0 & 124 & 82,7 \\
\hline 11 & $\begin{array}{l}\text { Percaya anggota } \\
\text { memiliki nilai intrinsik }\end{array}$ & 8 & 26,7 & 14 & 8,0 & 8 & 26,7 & 0 & 0,0 & 0 & 0,0 & 120 & 80,0 \\
\hline 12 & $\begin{array}{l}\text { Menghargai } \\
\text { perkembangan individu }\end{array}$ & 12 & 40,0 & 17 & 56,7 & 1 & 3,3 & 0 & 0,0 & 0 & 0,0 & 131 & 87,3 \\
\hline 13 & $\begin{array}{l}\text { Menghargai } \\
\text { perkembangan } \\
\text { profesionalisme }\end{array}$ & 16 & 53,3 & 14 & 46,7 & 0 & 0,0 & 0 & 0,0 & 0 & 0,0 & 136 & 90,7 \\
\hline 14 & $\begin{array}{l}\text { Menghargai } \\
\text { perkembangan spiritual }\end{array}$ & 21 & 70,0 & 7 & 23,3 & 2 & 6,7 & 0 & 0,0 & 0 & 0,0 & 139 & 92,7 \\
\hline 15 & $\begin{array}{l}\text { Berusaha membangaun } \\
\text { jalinan silaturahmi }\end{array}$ & 23 & 76,7 & 7 & 23,3 & 0 & 0,0 & 0 & 0,0 & 0 & 0,0 & 143 & 95,3 \\
\hline
\end{tabular}

Sumber: Hasil Olah Data Primer.

Hasil deskriptif yang ditampilkan dalam Tabel 2 di atas menunjukkan bahwa perguruan tinggi di Kota Palu sudah menunjukkan karakteristik servant leadership. Karakteristik-karakteristik yang ditunjukkan sangat membantu dalam penerapan servant leadership perguruan tinggi. Sebagaimana yang ditunjukkan Tabel 2, bahwa karakteristik servant leadership sangat didukung oleh adanya keinginan pimpinan yang selalu berusaha membangun jalinan silaturahmi untuk menjaga kekompakkan di antara anggota organisasi yang dalam hal ini kekompakkan anggota di perguruan tinggi, baik perguruan tinggi negeri maupun swasta di Kota Palu.

Hasil tersebut dibuktikan dengan adanya respon tinggi yang diberikan responden pada indikator berusaha membangaun jalinan silaturahmi (95,3\%). Hal itupun diikuti oleh indikator menjaga kekompakkan kelompok dan indikator menghargai perkembangan spiritual $(92,7 \%)$. Hasil tersebut menyimpulkan bahwa servant leadership perguruan tinggi di Kota Palu sudah ditunjukkan oleh pimpinan perguruan tinggi yang senantiasa menjaga kekompakan kelompok untuk memperlancar proses transformasi dan integrasi organisasi, serta adanya sikap pemimpin yang sangat menghargai perkembangan spiritual setiap anggota dalam organisasi yang dalam hal ini pada perguruan tinggi di Kota Palu.

Hasil tersebut senada dengan yang dikatakan Irving dalam Oktavia dan Devie (2014) bahwa servant leadership sebagai suatu proses dimana pemimpin dan para pengikutnya bekerja sama untuk mencapai visi organisasi. Kerja sama dalam penelitian ini sudah ditunjukkan oleh pemimpin perguruan tinggi yang memiliki karakter melayani dengan berupaya menjaga kekompakan dengan menjaga silaturahmi antar anggota.

Selain ketiga hal tersebut sudah dimiliki oleh pemimpin perguruan tinggi di Kota Palu, masih banyak karakter-karakter yang mendukung penerapan servant leadership di perguruan tinggi dan itu sudah ditunjukkan dari hasil penelitian ini. Hal tersebut dapat dilihat dari adanya karakter introspeksi diri, menghargai perkembangan profesionalisme, mendengarkan orang lain, berprasangka baik, menghargai perkembangan individu, melakukan pendekatan persuasif, berusaha mewujudkan visi, mengutamakan intuisi memecahkan masalah, percaya pada institusi memperbaiki taraf hidup, percaya anggota memiliki nilai intrinsik, dan secara umum mampu memahami kebutuhan orang lain, namun terdapat hal yang kurang dipahami oleh pemimpin perguruan tinggi di Kota Palu meskipun secara umum sudah dipahami, namun secara spesifik atau secara khusus pemimpin belum sepenuhnya dapat memahami kebutuhan khusus setiap anggota di perguruan tinggi yang dipimpinnya.

McMinn dalam Stone et al. (2003) menyatakan bahwa pemimpin pelayan mengembangkan orang, membantu mereka untuk maju dan berkembang. Hal itu juga dapat dilihat dari hasil penelitian ini yang menunjukkan adanya karakter-karakter yang mendukung penerapan servant leadership di perguruan tinggi seperti menghargai perkembangan profesionalisme, mendengarkan orang lain, berprasangka baik, menghargai perkembangan individu, melakukan pendekatan persuasif, berusaha mewujudkan 
visi, mengutamakan intuisi memecahkan masalah. Karakter-karakter tersebut menunjukkan bahwa servant leadership mampu mengembangkan orang, membantu mereka untuk maju dan berkembang.

Sementara itu, Liden et al. (2008) menjelaskan bahwa kepemimpinan pelayan menekankan integritas pribadi dan melayani orang lain, termasuk karyawan, pelanggan, dan masyarakat. Hal itu juga dapat dilihat dari hasil penelitian ini yang menunjukkan keberadaan karakter-karakter percaya pada institusi dalam memperbaiki taraf hidup, percaya bahwa anggota memiliki nilai intrinsik, dan secara umum mampu memahami kebutuhan orang lain, karena menurut Lantu \& Rumahorbo (2007) seorang pemimpin sejatinya adalah seorang pelayan.

Kepemimpianan yang melayani dimulai dari dalam diri seseorang. Kepemimpinan menuntut suatu transformasi dari dalam hati dan perubahan karakter. Kepemimpinan yang melayani dimulai dari dalam dan kemudian bergerak keluar untuk melayani mereka yang dipimpinnya. Disinilah pentingnya karakter dan integritas seorang pemimpin untuk menjadi pemimpin yang diterima oleh orang yang dipimpinnya.

Seorang pemimpin yang memiliki hati yang melayani orientasinya bukan untuk kepentingan diri pribadi maupun golongan tapi justru kepentingan publik yang dipimpinnya. Seorang pemimpin yang melayani merasa wajib melayani anggotanya dahulu lalu muncul dorongan kepadanya untuk memimpin. Pemimpin yang melayani adalah seorang pemimpin yang sangat peduli atas pertumbuhan dan dinamika kehidupan pengikut, dirinya dan komunitasnya dan karenanya ia mendahulukan hal-hal tersebut dibandingkan dengan pencapaian ambisi pribadi atau pola dan kesukaannya saja. Impiannya ialah agar orang yang dilayani tadi akan menjadi pemimpin yang melayani juga

Seorang pemimpin memiliki kerinduan untuk membangun dan mengembangkan mereka yang dipimpinnya sehingga tumbuh banyak pemimpin dalam kelomponya. Keberhasilan seorang pemimpin sangat tergantung dari kemampuannya untuk membangun orang- orang di sekitarnya, karena keberhasilan sebuah organisasi sangat tergantung pada potensi sumber daya manusia dalam organisasi tersebut. Jika sebuah organisasi atau masyarakat mempunyai banyak anggota dengan kualitas pemimpin, organisasi atau bangsa tersebut akan berkembang dan menjadi kuat.

Pemimpin yang melayani adalah pemimpin yang mau mendengar. Mau mendengar setiap kebutuhan, impian, dan harapan dari mereka yang dipimpin. Pemimpin yang melayani adalah pemimpin yang dapat mengendalikam ego dan kepentingan pribadinya melebihi kepentingan public atau mereka yang dipimpinnya. Mengendalikan ego berarti dapat mengendalikan diri ketika tekanan maupun tantangan yang dihadapi menjadi begitu berat,selalu dalam keadaan tenang, penuh pengendalian diri, dan tidak mudah emosi.

\section{KESIMPULAN DAN SARAN \\ Kesimpulan}

Berdasarkan hasil pembahasan, disimpulkan bahwa pimpinan beberapa perguruan tinggi di Kota Palu memiliki karakter kepemimpinan servant leadership pada berbagai aspek diantaranya berusaha membangaun jalinan silaturahmi, menjaga kekompakan kelompok, dan menghargai perkembangan spiritual, introspeksi diri, menghargai perkembangan profesionalisme, mendengarkan orang lain, berprasangka baik, menghargai perkembangan individu, melakukan pendekatan persuasif, berusaha mewujudkan visi, mengutamakan intuisi memecahkan masalah, percaya pada institusi untuk memperbaiki taraf hidup, percaya bahwa anggota memiliki nilai intrinsik, dan secara umum mampu memahami kebutuhan orang lain, namun secara khusus pemimpin belum sepenuhnya dapat memahami kebutuhan khusus setiap anggota organisasi di perguruan tinggi yang dipimpinnya.

\section{Saran}

Berdasarkan kesimpulan, disarankan kepada beberapa perguruan tinggi di Kota Palu untuk meningkatkan model servant leadership, terutama yang berkaitan dengan kemampuan memahami 
kebutuhan khusus setiap anggota organisasi di perguruan tinggi yang dipimpinnya, karena hal tersebut belum maksimal sehingga perlu ditingkatkan kembali.

\section{REFERENSI}

Bachtiar, N. (2013). Daya Saing Perguruan Tinggi. Padang: Fakultas Ekonomi-Universitas Andalas. Barbuto, J.E., and Wheeler, D.W. (2006). Scale Development and Construct Clarification of Servant Leadership. Group \& Organization Management, 31: 3, 300-326.

Basrowi dan Suwandi. (2008). Memahami Penelitian Kualitatif. Jakarta: Rineka Cipta.

Farling, M. L., Stone, A. G., \& Winston, B. E. (1999). Servant leadership: Setting the stage forempirical research. The Journal of Leadership Studies, 6, 49-72.

Goh, S.K, and Low, Brian Z.J. (2014). The Influence of Servant Leadership towards Organizational Commitment: The Mediating Role of Trust in Leaders. International Journal of Business and Management, Vol. 9, No. 1, 17-25.

Lantu, D., Pesiwarissa, E., and Rumahorbo, A. (2007). Servant Leadership. Yogyakarta: Gradien Books.

Liden, Robert C., Wayne, Sandy J., Zhao, Hao and Henderson, David J. (2008). Servant leadership: development of a multidimensional measure and multilevel assessment. The Leadership Quarterly, 19 (2), 161-177.

Oktavia, P.N., and Devie. 2014. Analisis Dampak Servant Leadership terhadap Competitive Advantage. Business Accounting Review, 2(2), 244-251.

Purwanto, S.K. (2015). Pengaruh Kepemimpinan Terhadap Kinerja Dosen di Perguruan Tinggi. Jurnal Manajemen, Vol. XIX, No. 01, 47-58.

Russell, R. F., and Stone, A. G. (2002). A review of servant leadership attributes: Developing a practical model. Leadership \& Organization Development Journal, 23(3), 145-157.

Sendjaya, S., Sarros, JC., and Santora, JC. (2008). Defining and measuring servant leadership behaviour in organizations. Journal of Management Studies, 45(2), 402-424.

Spears, L.C. (2010). Character and Servant Leadership: Ten Characteristics of Effective, Caring Leaders. The Journal of Virtues and Leadership, 1(1), 25-30.

Stone, A.G., Russell, R.F., and Patterson, K. (2003). Transformational versus Servant Leadership: A Difference in Leader Focus. Servant Leadership Research Roundtable. Published by the School of Leadership Studies, Regent University.

Sugiyono. (2010). Statistika untuk Penelitian. Bandung: Alfabeta.

Wong, T. P., and Page, D. (2000). A conceptual framework for measuring servant-leadership. In The human factor in shaping the course of history and development, ed. S. Abjibolosoo. Lanham, MD: University Press of America.

Wong, T. P., and Page, D. (2003). Servant leadership: An opponent-process model and the revised servant leadership profile. Presented at the Servant Leadership Research Roundtable, Virginia Beach, VA. 